\title{
PRODUCTIVITY LOSSES DUE TO MIGRAINE IN SLOVENIA: AN ANALYSIS OF ABSENTEEISM AND PRESENTEEISM COSTS BASED ON ADMINISTRATIVE AND SELF-REPORTED DATA STROŠKI IZGUB PRODUKTIVNOSTI ZARADI MIGRENE V SLOVENIJI: ANALIZA STROŠKOV ABSENTIZMA IN PREZENTIZMA NA PODLAGI PODATKOV IZ ADMINISTRATIVNEGA VIRA IN ANKETE
}

\author{
Aleša LOTRIČ DOLINAR ${ }^{1}$, Bojana ŽVAN², Petra DOŠENOVIĆ BONČA ${ }^{1 *}$ \\ 'University of Ljubljana, School of Economics and Business, Kardeljeva ploščad 17, 1000 Ljubljana, Slovenia \\ ${ }^{2}$ University Medical Centre Ljubljana, Zaloška cesta 7, 1000 Ljubljana, Slovenia
}

Received: Jun 17, 2019

Accepted: Jan 21, 2020
Original scientific article

\author{
ABSTRACT \\ Keywords: \\ migraine, economic \\ burden of illness, \\ absenteeism, \\ presenteeism, \\ indirect costs
}

\section{IZVLEČEK}

Ključne besede: migrena, ekonomsko breme bolezni, absentizem, prezentizem, posredni stroški
Introduction: Migraine is associated with significant morbidity and a significantly negative impact on the quality of life. A better understanding of the economic impact of migraine is becoming increasingly important. This paper aims to shed light on absenteeism and presenteeism costs of migraine in Slovenia.

Methods: We use the administrative national-level database on sick leave due to migraine for 2016. The absenteeism cost estimate is based on the number of patients with migraine on physician-determined sick leave and average daily labour costs. We calculate productivity costs from a social perspective regardless of who incurs them. Data from the national registry on sick leave are coupled with data from a web-based selfreported survey to also include the cost of presenteeism. MIDAS and WPAI presenteeism items were used and several different scenarios were designed to assess presenteeism costs.

Results: We estimated annual absenteeism costs per absentee due to migraine at the amount of EUR 531 in 2016 using the NIPH's administrative data on sick leave. Annual absenteeism costs per absentee due to migraine based on self-reported data amounted to EUR 626. The estimated annual presenteeism costs per patient range from EUR 344 - 900.

Conclusion: Estimating the economic burden of a disease is becoming increasingly important. This paper is an insight into the absenteeism and presenteeism costs of migraine in Slovenia.

Uvod: Migrena spada med pogoste kronične bolezni, ki ima močno negativen učinek tako na kakovost življenja samega prizadetega posameznika in njegovih bližnjih kot tudi na družbo kot celoto. Za boljše razumevanje slednjega postaja vse pomembnejše tudi ekonomsko vrednotenje tega negativnega učinka, vključno $\mathrm{z}$ upoštevanjem posrednih stroškov, med katerimi velja posebej izpostaviti stroške absentizma in prezentizma. $S$ tem prispevkom proučujemo stroške absentizma in prezentizma zaradi migrene $v$ Sloveniji.

Metode: Uporabili smo podatkovno bazo NIJZ za odsotnost zaradi migrene za leto 2016. Ocena stroškov absentizma temelji na številu pacientov z migreno in številu dni bolniških odsotnosti zaradi migrene, ki jo opredeli zdravnik ( $v$ nasprotju s samooceno, pridobljeno z različnimi vprašalniki). Želeli smo ovrednotiti stroške izgub produktivnosti $z$ družbenega vidika, zato smo $v$ ceni dela upoštevali tako povprečno neto plačo, $k i$ vključuje prispevke zaposlenih kot tudi prispevke delodajalcev. Poleg tega tudi nismo ločevali nadomestila za odsotnost z dela zaradi zdravstvenih razlogov, ki ga za krajše odsotnosti krije delodajalec, od nadomestila za daljše časovno obdobje, ki ga krije obvezno zavarovanje. Podatke iz nacionalne baze smo dopolnili s podatki, zbranimi s spletno anketo, na podlagi katerih smo lahko ocenili tudi stroške prezentizma. $V$ anketi sta bila kombinirana dva različna instrumenta za ovrednotenje stroškov prezentizma, in sicer MIDAS in WPAl, zato smo stroške prezentizma ocenili ob upoštevanju različnih scenarijev.

Rezultati: Ocenjeni povprečni letni strošek absentizma na koristnika staleža je bil 531 evrov v letu 2016, če smo upoštevali podatke iz nacionalne baze bolniškega staleža. Povprečni letni strošek absentizma na koristnika staleža na podlagi anketnih podatkov pa je znašal 626 evrov. Ocena letnih stroškov prezentizma na pacienta se ob upoštevanju omenjenih različnih scenarijev giblje na širokem intervalu med 344 in 900 evri.

Sklep: Za ustrezno obvladovanje bolezni je ključnega pomena ustrezno ovrednotenje z boleznijo povezanega bremena. Če že ne moremo oceniti oviranosti, ki jo posamezniku in njegovim bližnjim predstavljajo bolečina in z njo povezane omejitve, je ekonomsko breme bolezni bolj otipljivo. Pri oceni ekonomskega bremena je bistveno, da so poleg neposrednih stroškov bolezni upoštevani tudi posredni stroški. $V$ tem prispevku se osredotočamo na ocenjevanje stroškov absentizma in prezentizma zaradi migrene $v$ Sloveniji. 


\section{INTRODUCTION}

Migraine is a very common headache disorder affecting around $12-14 \%$ of adults, with significant negative impacts on the quality of life $(1,2)$. There is a lack of adequately collected epidemiological data on headache and migraine in Slovenia. The 2012 study (3) of the adult working population has shown that the prevalence of headaches was $38.1 \%$. Migraine represents a setback not only for the affected person but also for society as a whole. Researchers and policy-makers explore both the direct and indirect costs of migraine to determine its economic burden (4). Being incurred by the health system, society, family and individual patients, the direct costs consist of healthcare costs such as medical care expenditures and non-healthcare costs such as transportation, relocating and informal care (5). Indirect costs include productivity losses borne by the individual, family, society, or the employer due to absenteeism, presenteeism, premature death and economic inactivity as well as losses in education and job promotion, unwanted job changes, lost time from work for caregivers, and replacement market value for lost domestic services $(5,6)$.

Early research on the economic burden of migraine began in the USA (7). Increasingly more is now known about it also in Europe. While there are large differences in estimated costs between countries due to methodological differences (6), most studies show that indirect costs exceed the direct costs $(6,8-10)$. An influential paper by Linde et al. (10) found that indirect costs of migraine accounted for $93 \%$ of all costs, two-thirds of which were attributable to reduced productivity, i.e. presenteeism, rather than absenteeism. Other studies $(6,11-13)$ also support this conclusion. An average efficiency level when working with a migraine was estimated at $65 \%$ (11) and even $56 \%$ (13). A recent US study (14) that evaluated presenteeism among employees showed that migraine is among the conditions with the highest estimated daily productivity loss and annual cost per person.

Costs of migraine have also been estimated for Slovenia $(15,16)$. The more recent study (16) allocated a $74 \%$ share of all costs to indirect costs, thereby supporting the conclusions of studies for other countries. However, these estimates are based on extrapolated data from the European study on costs of brain disorders for 2010 (8) and exclude presenteeism costs.

The aim of this paper is to investigate both absenteeism and presenteeism costs of migraine in Slovenia. We contribute to existing research for Slovenia $(15,16)$ because our calculations do not build on extrapolated data based on foreign studies, but on national level sick leave data provided by the Slovenian National Institute of Public Health (NIPH) and on a small retrospective selfreported study of migraine that also incorporated the
MIDAS and WPAl items on absenteeism and presenteeism. This enables us to estimate both absenteeism and presenteeism costs while previous research for Slovenia addressed lost production due to work absence and early retirement.

\section{METHODS}

Estimating productivity costs requires selecting both a suitable approach for assigning a monetary value to lost productivity and an appropriate measurement method for absenteeism and presenteeism.

\subsection{Valuation of Lost Productivity}

We adopt the human capital method that takes the earnings of an individual as a proxy for their productivity (17). To calculate productivity costs, we use the daily labour costs per worker separately for both genders in 2016, given that the studied administrative data on absenteeism refer to this year. In Slovenia, the average daily labour costs amounted to EUR 90.17 for women and EUR 95.81 for men in 2016 (18).

Average daily labour costs are calculated by dividing respective annual labour costs by the 252 working days in Slovenia in 2016. Annual labour costs per worker are calculated based on the labour cost structural statistics of the Statistical Office of Slovenia. They comprise wages and salaries, including social contributions payable by employees, social contributions paid by employers and other expenditures paid by the employers. In Slovenia, persons with compulsory insurance are entitled to a sickness cash benefit that for patients with migraine typically amounts to $80 \%$ of their earnings. The sickness cash benefit is paid either by the employer or the Health Insurance Institute of Slovenia, depending on the length of absence. By estimating absenteeism costs using daily labour costs per worker, we capture both the 20\% share of the burden carried by patients and the $80 \%$ share of absenteeism costs incurred by either the employer or the social insurance fund. We thus calculate absenteeism costs from a social perspective regardless of who incurs them.

One important pitfall of the human capital approach is that differences in absenteeism costs between different diseases may be a consequence of wage differences rather than the actual length of absences and the levels of impairment (9). In such circumstances, estimates of indirect costs for illnesses affecting mostly manual uneducated labour or women may underestimate their burden of illness. This is relevant also for migraine since prevalence, incidence and remission rates vary by sex, socioeconomic status and other factors (19). This is why we use both average overall daily labour cost and average 
gender-specific daily labour costs in Slovenia. In 2016, the average daily labour cost per worker for both genders combined equalled EUR 93.21 (18). Educational-level and profession-specific labour costs are not used, as available datasets do not incorporate this information about the studied migraineurs.

\subsection{Estimating Absenteeism Costs}

Absenteeism is estimated using the national sick-leave database, coupled with data from the self-reported study that includes the Migraine Disability Assessment Test (MIDAS) and Work Productivity and Activity Impairment (WPAl) items, measuring absenteeism and presenteeism. We use the administrative database of the NIPH on sick leave due to migraine for 2016. Surveys reflect patients' subjective perceptions about the type of their headaches, whereas in our administrative database the diagnoses are recorded by medical professionals at the time of sick leave occurrences according to the International Classification of Diseases (Version ICD-10-AM). This database includes the entire population of employed individuals and others entitled to sickness benefits that are on formal sick leave due to migraine rather than a specific sample. Parttime employees and self-employed individuals as well as employees with flexible work schedules, who take formal sick leave less often, represent a small share. The database for 2016 consists of 2,416 records of absence from work of full-time employees due to migraine. These records refer to 1,743 patients. Besides the duration of sick leave, information on gender, age group and month of the sick leave termination are also available. Absenteeism costs based on administrative data are estimated using Equation 1.

Annual absenteeism cost per absentee

$$
\begin{aligned}
& =\sum_{i=1}^{N=1743} \text { (length of sick leave } i \\
& \times \text { average (overall) daily labour costs) } \div N
\end{aligned}
$$

The length of sick leave is the yearly number of days off work for an individual patient with diagnosed migraine (code G43 of ICD-10-AM). Average overall labour costs are specified in Section 2.1. Eq. 1 is modified by replacing the average overall daily labour costs with the average gender-specific daily labour costs to determine the gender-specific absenteeism costs.

Absenteeism is also studied based on the data from a wider self-reported study (20). A web survey using a recall period of 3 months was conducted between 15 November and 12 December 2017 to analyse the prevalence of headache and migraine, their impact on the working population and the treatment processes. A total of 1,207 adult employees with headaches, in addition to 102 general practitioners and 50 neurologists, were surveyed.
There were 146 migraineurs out of 1,207 respondents. After excluding outliers (i.e., patients outside the range of three standard deviations from the mean number of days at work affected by migraine) 142 migraineurs were included in the analysis. The survey comprises 20 questions referring to the diagnosis, the current disease treatment and management, the use of headache diaries, migraine's adverse effects and the productivity losses. One item capturing absenteeism is from the MIDAS instrument, which is one of the most widely used questionnaires to measure the impact of headaches on work functioning and is also included in the Slovenian national guidelines for treatment of migraine (21).

This item measures the number of days lost form work or school in the last 3 months. Absenteeism costs estimated using this approach are calculated using Equation 2.

Absenteeism cost per absentee in a 3-month period

$$
\begin{aligned}
& =\quad \sum_{i=1}^{n=142}\left(\text { no.of days out of work in the last } 3 \text { months } s_{i} \quad\right. \text { (Eq. 2) } \\
& \times \quad \text { average (overall) daily labour costs }) \div n
\end{aligned}
$$

Eq. 2 is also modified by replacing the average overall daily labour costs with the average gender-specific daily labour costs from Section 2.1.

An important challenge of using self-reported data with a 3-month recall is the calculation of absenteeism costs at an annual level. The national-level data on sick leave indicate that the frequency and intensity of sick leave is not constant throughout the year. To extrapolate results from the 3-month period covered by the survey to the annual level, we introduce conversion factors estimated from the administrative data on sick leave. Conversion factors are estimated by comparing average absences from work in a corresponding 3-month period to the average absences on an annual level.

\subsection{Estimating Presenteeism Costs}

Presenteeism is studied using the MIDAS and WPAI instruments, each including one presenteeism item (22).

In the WPAI presenteeism item, 0 indicates no effect on work and 10 complete prevention from working. The estimated presenteeism costs based on this WPAl item are calculated using Equation 3.

\footnotetext{
Presenteeism cost per patient in a 3-month period$$
=\sum_{i=1}^{n=142}\left(\text { no. of work days with reduced productivity in the last } 3 \text { months } s_{i}\right.
$$$$
\times \quad \text { impairment while working with migraine }{ }_{i} / 10
$$$$
x \text { average (overall) daily labour costs) } \div n
$$

(Eq. 3) 
The number of working days with reduced productivity in the last 3 months is determined as the difference between the number of migraine days and the number of days of absence from work in this same period.

MIDAS identifies the number of days at work with substantially reduced productivity (i.e. more than 50\%) over a 3-month period. The estimated presenteeism costs based on this MIDAS item are calculated using Equation 4.

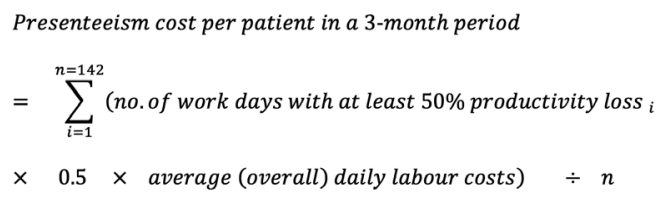

To enable a comparison between estimated presenteeism and absenteeism costs, the former need to be extrapolated from a 3-month period to an annual level. We do this using conversion factors from Section 2.2. We thus assume that migraine intensity within the observed 3-month period compared to the whole year had a comparable effect on both absenteeism and presenteeism.

\section{RESULTS}

\subsection{Absenteeism Costs}

Figure 1 shows the distribution of the 1,743 migraineurs on sick leave from the national database in 2016 by age and gender $(85.4 \%$ women, $14.6 \%$ men). Over $80 \%$ of migrainerelated absences lasted for up to five days. The average annual length of absence from work due to migraine was 5.70 days, 5.65 for women and 5.96 for men.

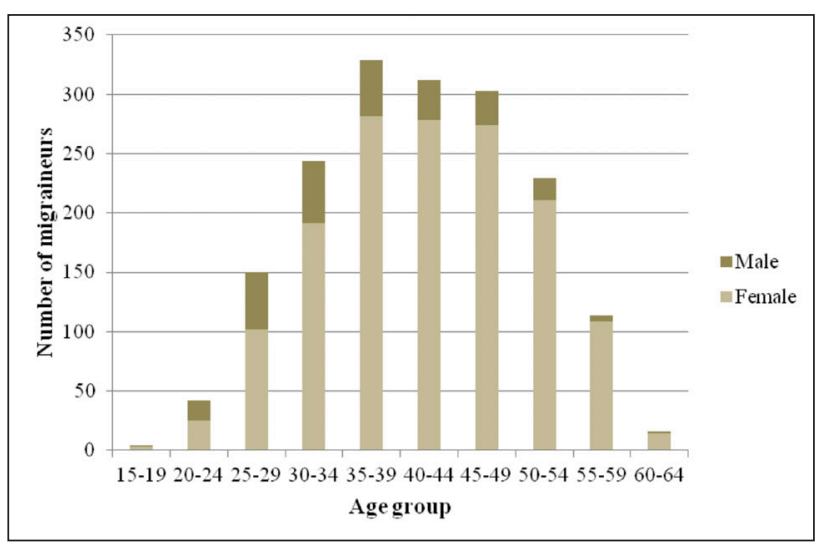

Figure 1. Distribution of migraineurs by 5 -year age groups and gender, national database, 2016.
The average annual absenteeism cost per absentee estimated using Eq. 1 amounted to EUR 531. The total annual absenteeism cost for all 1,743 migraineurs on formal sick leave in 2016 is thus estimated at EUR 925,762. Table 1 shows the results for both genders combined and stratified by gender, estimated at labour costs from Section 2.1.

Table 1. Absenteeism costs for migraine in Slovenia, full-time employees, 2016, EUR.

\begin{tabular}{lccc}
\hline & \multicolumn{3}{c}{ Gender } \\
\cline { 2 - 4 } & Female & Male & Total \\
\hline $\begin{array}{l}\text { Average length of } \\
\text { sick leave (days) }\end{array}$ & 5.65 & 5.96 & 5.70 \\
$\begin{array}{l}\text { Average annual cost } \\
\text { per absentee }\end{array}$ & 527 & 555 & 531 \\
$\begin{array}{l}\text { Gender-specific } \\
\text { average annual cost } \\
\text { per absentee }\end{array}$ & 510 & 571 & 519 \\
$\begin{array}{l}\text { Total annual } \\
\text { absenteeism cost }\end{array}$ & & & \\
$\begin{array}{l}\text { Gender-specific } \\
\text { total annual } \\
\text { absenteeism cost }\end{array}$ & 784,735 & 141,027 & 925,762 \\
\hline
\end{tabular}

Note:

1 - calculated with the average overall labour cost for both genders combined in 2016

2 - calculated with the average gender-specific labour cost in 2016

We also estimate absenteeism costs using the selfreported data and Eq. 2. The self-reported average length of absence from work in a 3-month period was 4.40 days (4.18 for women and 4.89 for men).

These results are not directly comparable to the results based on the national database due to differences in the covered period. To enable a comparison, we use the administrative data to determine the average absence from work only for the period from September to November 2016. This time span is observed because the autumn period is also included in the survey and this helps us control possible seasonal triggers of migraine. In the above-mentioned 3-month period, there were 594 patients recorded in the national sick leave database with approximately the same gender proportion as in the whole year of 2016. Their 3-month average absence length was 3.77 days, 3.78 and 3.75 for women and men, respectively. By comparing the average length of absences from work in the three months in autumn to the annual average absences reported in Table 1, we calculate the 1-year-to-3-month ratios equalling 1.510 for both genders combined, 1.497 for women and 1.588 for men for 2016. 
The estimated self-reported absenteeism costs calculated on the annual level amount to EUR 626 per absentee for both genders combined, thus exceeding the cost estimated using administrative data by $18 \%$ (11\% for women and $30 \%$ for men).

\subsection{Presenteeism Costs}

According to Eq. 3, we need both the number of working days with reduced productivity and the efficiency while working with a migraine to estimate the presenteeism cost per absentee in a 3-month period (Figure 2). Over $50 \%$ of migraineurs stated that their level of impairment while working with a migraine was between 5 and 7 (out of 10).

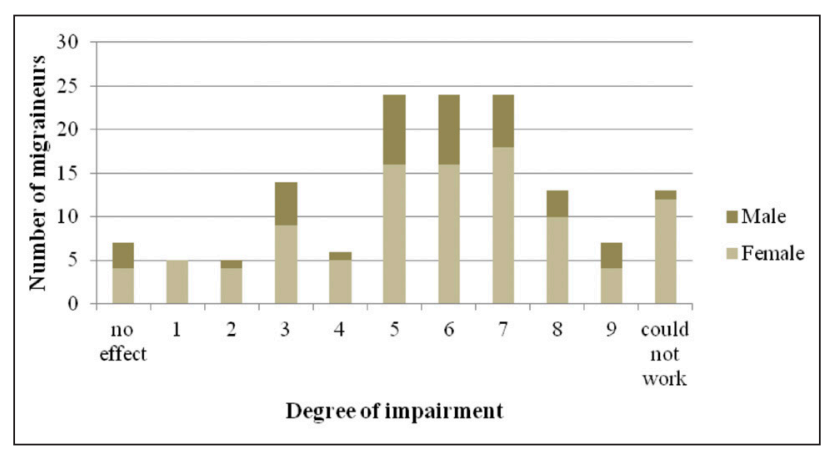

Figure 2. Distribution of self-assessed degree of impairment while working with migraine by gender.

According to the survey, most respondents, i.e. $75.4 \%$ (72.8\% for women and $82.1 \%$ for men), report that the average number of migraine days per month is less than 4 . One problem in the calculation of the number of working days with reduced productivity arises from the survey's design. Specifically, the question regarding the length of absence provided different pre-determined intervals. To overcome this problem, we calculate the presenteeism costs by considering several different scenarios shown in Table 2, i.e. 1) taking the lower bounds of the intervals, 2) taking the middle points of the intervals and 3 ) taking the upper bounds of the intervals as the relevant value for the number of migraine days per month. The upper limit of the last interval is set at the maximum number of working days within a month.

Table 2. Intervals for the average number of migraine days per month and the assigned value under different scenarios.

\begin{tabular}{lccc}
\hline $\begin{array}{l}\text { Average number of } \\
\text { migraine days per } \\
\text { month }\end{array}$ & Min & Middle & Max \\
\cline { 2 - 4 } & 1 & 2 & 3 \\
Less than 4 days & 4 & 5.5 & 7 \\
4-7 days & 8 & 11 & 14 \\
8-14 days & 15 & 18.5 & 22 \\
\hline 15 or more days & & & \\
\hline
\end{tabular}

The estimated annual presenteeism costs in three different scenarios are presented in Table 3 . The survey enables estimates for the observed 3-month period. To enable comparisons of presenteeism costs with absenteeism costs, we converted the 3-month values to the annual level using the conversion factors calculated in Section 3.1 .

Given that both the conversion factors and the daily labour cost per worker are for 2016, the estimated presenteeism costs in Table 3 also refer to 2016 to enable comparability with estimated absenteeism costs.

Table 3. Estimated annual presenteeism cost per patient, three scenarios, Slovenia, 2016, EUR.

\begin{tabular}{|c|c|c|c|c|c|c|}
\hline \multirow[t]{2}{*}{ Scenario } & \multicolumn{3}{|c|}{$\begin{array}{l}\text { Average annual cost based on } \\
\text { overall labour cost (EUR) }\end{array}$} & \multicolumn{3}{|c|}{$\begin{array}{l}\text { Average annual cost based on } \\
\text { gender-specific labour cost (EUR) }\end{array}$} \\
\hline & Female & Male & Total & Female & Male & Total \\
\hline Min & 401 & 267 & 364 & 388 & 275 & 357 \\
\hline Middle & 668 & 503 & 623 & 646 & 517 & 611 \\
\hline Max & 950 & 767 & 900 & 919 & 789 & 883 \\
\hline
\end{tabular}

Notes:

1 - calculated with average overall labour cost for both genders combined in 2016

2 - calculated with average gender-specific labour cost in 2016 
The results presented above refer to the WPAI presenteeism item. By using Eq. 4, we estimate presenteeism costs using the MIDAS presenteeism item as well (Table 4). A specific number of days with substantially reduced productivity was reported directly by the surveyed patients. Again, the 3 -month values were extrapolated to the annual level by using the conversion factors from Section 3.1.

Table 4. Estimated annual presenteeism cost per patient based on the number of days with $50 \%$ productivity impairment, Slovenia, 2016, EUR.

\begin{tabular}{lccc}
\hline & \multicolumn{3}{c}{ Gender } \\
\cline { 2 - 4 } & Female & Male & Total \\
\hline $\begin{array}{l}\text { Average annual } \\
\text { number of days with } \\
\text { substantially reduced } \\
\text { productivity }\end{array}$ & 7.27 & 8.10 & 7.50 \\
$\begin{array}{l}\text { General average annual } \\
\text { cost per patient }\end{array}$ & 339 & 378 & 349 \\
$\begin{array}{l}\text { Gender-specific average } \\
\text { annual cost per patient }\end{array}{ }^{2}$ & 328 & 388 & 344 \\
\hline
\end{tabular}

Notes:

1 - calculated with the average overall labour cost for both genders combined in 2016

2 - calculated with the average gender-specific labour cost in 2016

\section{DISCUSSION}

Methods such as the friction cost method (23), the willingness to pay method (24) and the human capital approach $(17,11,10)$ are used to assign a monetary value to lost productivity. We use the human capital approach, which is most widely used in other studies and has also been used in previous research for Slovenia $(15,16)$. We use both overall and gender-specific annual labour costs per worker as a proxy for their productivity and calculate absenteeism costs from a social perspective regardless of who incurs them (the patient, the employer or the social insurance fund). We use the average overall labour costs to prevent wage differences from influencing the estimated productivity costs. Such estimates reflect differences in actual length of absences and levels of impairment without wage gap distortions (9). The estimated overall and gender-specific results are similar, as the gender labour cost gap is low (EUR 90.17 for women and EUR 95.81 for men in 2016). Given that prevalence of migraine is higher in lower income and lower educational groups (19), it would be beneficial to also estimate productivity costs using actual labour costs of the studied migraineurs. The necessary information, however, is not included in the available datasets. Educational-level-specific results would probably differ more notably from our gender- specific results. The average daily labour costs for those with primary education are $34.6 \%$ below the overall average while for those with tertiary education they are $38.4 \%$ above the overall average (18).

A wide array of approaches for measuring productivity losses is used. A top-down method based on national registries is mostly used for estimating direct costs, while a bottom-up approach is applied for indirect costs using retrospective population-based studies with different recall periods (11). Different instruments have been used to assess illness-related productivity losses. Papers addressing migraine from a relevant systematic review (25) adopted, for example, the Health and Labour Questionnaire, Work Productivity Short Inventory and the 13-item Stanford Presenteeism Scale. Another review (26) also included 7 papers on presenteeism for migraineurs using MIDAS, the Migraine Work and Productivity Loss Questionnaire - MWPLQ and the Osterhaus Technique. Another review (27) recommended two instruments for migraine, i.e. the Employer Health Coalition of Tampa Assessment Instrument and the MWPLQ. Some recent papers on migraine expand the array to the WPAI (28) and different versions of the HALT questionnaire (29). In our study, we combine both the administrative sick-leave database and the self-reported survey combining the WPAl used in some of the more recent studies (28) and the widely used MIDAS, which is also included in Slovenian national guidelines for migraine treatment (21).

We estimated the annual absenteeism costs per absentee at the amount of EUR 531 in 2016, using the NIPH's administrative data on sick leave due to migraine. Annual absenteeism costs per absentee due to migraine based on self-reported data amounted to EUR 626. Results based on the 3-month survey data were extrapolated to the annual level by taking into consideration the seasonal variation revealed by the administrative database. We thus took a different approach from most studies that collect data for a limited time period and then recalculate these figures pro-rata to obtain days lost from work over a 12-month period (e.g. 13). Results based on self-reported data exceed those based on administrative data by $18 \%$. This could be due to underrepresentation of employees with flexible working arrangements in the administrative database. The estimated absenteeism costs also exceed the previously estimated indirect costs for Slovenia ranging from EUR PPP 181 - 191 (15, 16). These estimates cover lost production due to work absence and early retirement and are not comparable with our results because they extrapolate from foreign studies. They are also lower considering that gross wages and not total labour costs are used for the purpose of valuation.

The estimated annual presenteeism costs per patient with a migraine range from EUR 344 to 900 . Lowest estimates are calculated based on the number of days with substantially 
(more than 50\%) reduced productivity that disregards those days when patients are impacted by migraine to a lesser degree. Results obtained with the minimum and middle scenarios for the number of days affected by migraine are EUR 364 and 623, respectively. An overview of published cost studies for migraine in Europe (11) shows a wide variation in the estimated presenteeism cost per patient between different countries (EUR 50 in Sweden, EUR 138 in the Netherlands, EUR 356 in Germany and EUR 365 in the UK). Another survey in eight countries representing $55 \%$ of the adult EU population (10) showed that the mean per-person annual presenteeism costs of migraine amount to EUR 765. Two recent studies show that absenteeism and presenteeism costs equal EUR 535 in Latvia and EUR 483 in Lithuania (30). Our larger estimates can be explained, firstly, by the fact that most respondents reported a high level of impairment while working with migraine (between 5 and 7), which is below the average efficiency levels from other studies (e.g. 56\% (13) and 65\% (11)). Secondly, we use total labour costs and not just wages to estimate productivity costs. Thirdly, we use overall average daily labour costs thereby disregarding the fact that migraine prevalence is higher for low income groups.

Several limitations of our study need to be addressed. Both the national-level sick leave database and the data from a web-based study have some shortcomings. The administrative database consists of formal sick leave predominantly for full-time employees and there is weak representation of employees with more flexible work arrangements. The sample in the self-reported study is small and non-random. Therefore, the results cannot be considered as statistical estimates but can, nevertheless, provide some insight into absenteeism and presenteeism due to migraine in Slovenia. While reporting bias is an issue when using administrative data, recall bias is involved in self-reported studies. Furthermore, the questionnaire only targets a 3-month period, thereby complicating the drawing of conclusions at an annual level. An additional limitation of our study is that we do not use a control group, which could allow a more specific allocation of productivity losses to migraine. The fact is, migraine has a high comorbidity rate (e.g. 31, 32) and it is not always possible to distinguish between absenteeism due to comorbidity and migraine itself. Another limitation is that we address absenteeism and presenteeism costs but fail to incorporate early retirement, work inactivity, unemployment or underemployment, fewer opportunities for promotion and education, unintended changes in occupation and the burden on informal caregivers. We also disregard impairment of social life and leisure activities and fail to include productivity losses for persons engaged exclusively in domestic production (33).

One of the key strengths of our study lies in its twofold contribution to existing research for Slovenia. Firstly, previous estimates $(15,16)$ were calculated from extrapolated data of studies for other countries, while our estimates are based on self-reported and administrative data for the Slovenian population. Secondly, we estimate both gender-specific and overall absenteeism and presenteeism costs.

\section{CONCLUSIONS}

We estimated the annual absenteeism costs per absentee due to migraine at the amount of EUR 531 in 2016 using the NIPH's administrative data on sick leave. The annual absenteeism costs per absentee due to migraine based on self-reported data amounted to EUR 626. The presenteeism costs were assessed under different scenarios based on a self-reported study including MIDAS and WPAI presenteeism items. The estimated annual presenteeism costs per patient range from EUR 344 to 900 .

\section{CONFLICTS OF INTEREST}

The core data of the article is derived from a survey conducted by Ipsos and funded by Novartis. The authors of the article declare that no conflicts of interest exist in terms of this article's content.

\section{FUNDING}

This work was supported by the Slovenian Research Agency [grant number P5-0117].

\section{ETHICAL APPROVAL}

Not applicable.

\section{REFERENCES}

1. Bigal ME, Serrano D, Reed M, Lipton RB. Chronic migraine in the population - burden, diagnosis, and satisfaction with treatment. Neurology. 2008;71(8):559-66. doi: 10.1212/01.wnl.0000323925.29520. e7.

2. Stovner LJ et al. Global, regional, and national burden of migraine and tension-type headache, 1990-2016: a systematic analysis for the Global Burden of Disease Study 2016. Lancet Neurol. 2018;17:954-76. doi: 10.1016/S1474-4422(18)30322-3.

3. Zaletel-Kragelj L, Zaletel M, Eržen I. Ocena prevalence glavobola $\checkmark$ splošni populaciji odraslih prebivalcev Slovenije glede na izbrane dejavnike. In: Žvan B, Zaletel M, Zupan M, editors. Migrena 2018: zbornik poglavij strokovnega srečanja in učbenik za zdravnike, zdravstvene delavce in študente Medicinske in Zdravstvene fakultete. Ljubljana: Društvo za preprečevanje možganskih in žilnih bolezni, 2018: 27-40. 
4. Byford S, Torgerson D J, Raftery J. Economic note: cost of illness studies. BMJ. 2000;320(7245):1335. doi: 10.1136/bmj.320.7245.1335.

5. Jo C. Cost-of-illness studies: concepts, scopes, and methods. Clin Mol Hepatol. 2014;20(4):327-37. doi: 10.3350/cmh.2014.20.4.327.

6. Ferrari MD. The economic burden of migraine to society. Pharmacoeconomics. 1998;13(6):667-76. doi: 10.2165/00019053199813060-00003.

7. Osterhaus JT, Gutterman DL, Plachetka JR. Healthcare resource and lost labour costs of migraine headache in the US. Pharmacoeconomics. 1992;2(1):67-76. doi: 10.2165/00019053-199202010-00008

8. Gustavsson A, Svensson M, Jacobi F, Allgulander C, Alonso J, Beghi E, et al. Cost of disorders of the brain in Europe 2010. Eur Neuropsychopharmacol. 2011;21(10):718- 79. doi: 10.1016/j. euroneuro.2011.08.008.

9. Badia X, Magaz S, Gutierres L, Galvan J. The burden of migraine in Spain: beyond direct costs. Pharmacoeconomics. 2004;22(9):591-603. doi: 10.2165/00019053-200422090-00004.

10. Linde M, Gustavsson A, Stovner LJ, Steiner TJ, Barre J, Katsarava Z, et al. The cost of headache disorders in Europe: the Eurolight project. Eur J Neurol. 2012;19(5):703- 11. doi: 10.1111/j.1468-1331.2011.03612.x.

11. Berg J. Economic evidence in migraine and other headaches: a review. Eur J Health Econ. 2004;5(Suppl I):43-54. doi: 10.1007/s10198-0050288-z.

12. Bigal ME, Moraes FA, Fernandes LC, Bordini CA, Speciali JG. Indirect costs of migraine in a public Brazilian hospital. Headache. 2001;41(5):503-8. doi: 10.1046/j.1526-4610.2001.01089.x.

13. Clarke CE, MacMillan L, Sondhi S, Wells NE. Economic and social impact of migraine. QJM. 1996;89(1):77-84. doi: 10.1093/oxfordjournals. qjmed.a030141.

14. Allen D, Hines EW, Pazdernik V, Konecny LT, Breitenbach E. Fouryear review of presenteeism data among employees of a large United States health care system: a retrospective prevalence study. Hum Resour Health. 2018;16(1):59. doi: 10.1186/s12960-018-0321-9.

15. Vodušek DB, Kos M, Dolenc VV, Tomori M, Neubauer D, Sobocki P. Cost of disorders of the brain in Slovenia. Zdrav Vestn. 2008;77(Suppl II):5-11.

16. Bon J, Koritnik B, Bresjanac M, Repovs G, Pregelj P, Dobnik B, et al. Cost of disorders of the brain in Slovenia in 2010. Zdrav Vestn. 2013;82(3):164-75. Accessed May 31st, 2019 at: https://vestnik.szd.si/ index.php/ZdravVest/article/view/724.

17. Becker G. Human capital. 3rd ed. Chicago: Chicago University Press, 1993.

18. SURS. SI-STAT database. Structure of earnings statistics - annual data. Accessed April 1st, 2019 at: https://pxweb.stat.si/pxweb/Database/ Demographics/07_labour_force/10_earnings_costs/03_07113_ structure_stats/03_07113_structure_stats.asp

19. Stewart WF, Roy J, Lipton RB. Migraine prevalence, socioeconomic status, and social causation. Neurology. 2013;81(11):948-55. doi: 10.1212/WNL.0b013e3182a43b32.
20. Zaletel M, Keček-Plešec K, Pegam A, Žvan B. Prevalenca glavobola in migrene $v$ slovenski delovno aktivni populaciji ter njun vpliv na produktivnost. In: Žvan B, Zaletel M, Zupan M, editors. Akutna možganska kap XII. Ljubljana: Društvo za preprečevanje možganskih in žilnih bolezni, 2018:177-86.

21. Žvan B, Zaletel M, Pogačnik T. Slovenske smernice za obravnavo migrene 2006. Ljubljana: Društvo za preprečevanje možganskih in žilnih bolezni, 2006.

22. Ospina MB, Dennett L, Waye A, Jacobs P, Thompson AH. A systematic review of measurement properties of instruments assessing presenteeism. Am J Manag Care. 2015 1;21(2):e171-85.

23. van Roijen L, Essink-Bot ML, Koopmanschap MA, Michel BC, Rutten FFH. Societal perspective on the burden of migraine in The Netherlands. Pharmacoeconomics. 1995;7(2):170-9. doi: 10.2165/00019053. $199507020-00008$.

24. Groot W, Maassen van den Brink H. A direct method for estimating the compensating income variation for severe headache and migraine. Soc Sci Med. 2004;58(2):305-14. doi: 10.1016/S0277-9536(03)00208-9.

25. Noben CYG, Evers SMAA, Nijhuis FJ, de Rijk AE. Quality appraisal of generic self-reported instruments measuring health-related productivity changes: a systematic review. BMC Public Health. 2014;4(14):115. doi: 10.1186/1471-2458-14-115.

26. Ospina MB, Dennett L, Waye A, Jacobs P, Thompson AH. A systematic review of measurement properties of instruments assessing presenteeism. Am J Manag Care. 2015;21(2): e171-85. doi: 10.2165/00019053-199813060-00003.

27. Loeppke R, Hymel PA, Lofland JH, Pizzi LT, Konicki DL, Anstadt GW, et al. Health-related workplace productivity measurement: general and migraine-specific recommendations from the ACOEM expert panel. J Occup Environ Med. 2003;45(4):349-59. doi: 10.1097/01. jom.0000063619.37065.e2.

28. Lipton RB, Gandhi SK, Fitzgerald T, Yeung PP, Cohen JM, Yang R, et al. The positive impact of fremanezumab on work productivity and activity impairment in patients with chronic migraine. Neurology. 2018;90(Suppl 15):32.007. Accessed May 31st, 2019 at: https://n. neurology.org/content/90/15_Supplement/S32.007.

29. Steiner TJ, Lipton RB. The Headache-Attributed Lost Time (HALT) Indices: measures of burden for clinical management and populationbased research. J Headache Pain. 2018;19(1):12. doi: 10.1186/s10194018-0837-3.

30. Lublóy Á. Economic burden of migraine in Latvia and Lithuania: direct and indirect costs. BMC Public Health. 2019;19:1242. doi: 10.1186/ s12889-019-7461-2.

31. D’Amico D, Sansone E, Grazzi L, Giovannetti AM, Leonardi M, Schiavolin $S$, et al. Multimorbidity in patients with chronic migraine and medication overuse headache. Acta Neurol Scand. 2018;138(6):515522. doi: 10.1111/ane.13014.

32. Rammohan K, Mundayadan SM, Das S, Shaji CV. Migraine and mood disorders: prevalence, clinical correlations and disability. J Neurosci Rural Pract. 2019;10(1):28-33. doi: 10.4103/jnrp.jnrp_146_18.

33. Fishman $P$, Black L. Indirect costs of migraine in a managed care population. Cephalalgia. 1999;19(1):50-7. doi: 10.1046/j.14682982.1999.1901050.x. 